\title{
On the Essential Nature of Hematopoietic Function of Bone Marrow
}

Report 1. On the Monophasis of Mitosis in the Erythropoietic System and the Diphasis of Mitosis in the Leucopoietic System in the Bone Marrow

By

\section{Akira Saito}

From the Medical Department of Prof. S. Y amagata, Tohoku University School of Medicine, Sendai

(Received for Publication, March 14, 1961)

\section{PREFACE}

The author has found that the essential difference between leucocytosis and leucopenia originates from the diphasis of mitosis in the leucopoietic system in the bone marrow ${ }^{1-15}$.

On the basis of this result, the principle of hematopoiesis in the bone marrow will be discussed in these reports.

1. In the ordinary clinic, the cases in which leucocytosis appears are as follows :

1) Coccal and bacillary infections: pneumonia, bronchopneumonia, Asiatic cholera, bronchitis, meningitis epidemica, erysipelas, scarlet fever, sepsis, gonorrhoea, tonsillitis, lymphadenitis submaxillaris, otitis media, liver abscess, appendicitis, puerperal fever, dysentery, pertussis, diphtheria and other infectious and purulent diseases; spirochetosis: syphilis, relapsing fever, Weil's disease; rickettsial diseases: eruptive typhus; viral diseases: various kinds of encephalitis, lyssa, small pox and other infectious and purulent diseases.

2) Chemical agents and drugs.

a) sodium nucleinate and various kinds of acid, potassium chlorate, chrome, phenylhydrazine; antipyretics, i.e. acetanilide, phenacetin, etc.; pyridine, epinephrine, turpentine, camphor, digitalis, pyrogallol.

b) Metabolic products: in uremia, diabetic acidosis, eclampsia, gout and burns and so on.

3) Acute hemorrhage.

4) Postoperatively.

5) Non-inflammatory conditions, such as coronary thrombosis.

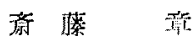


6) Malignant neoplasms.

7) Hemolysis of erythrocytes.

8) Physiological cases : in newborn children, during labor, after repeated vomiting and convulsions.

2. Leucopenia appears in the following cases :

1) Bacterial infectious diseases: typhoid and paratyphoid fevers, Bang's disease, Malta-fever; rickettsiosis: Japanese river fever, Ezô-fever, Shichitôfever; viral diseases: measles, rubeola, poliomyelitis, influenza, hepatitis epidemica, mumps, dengue, Pappataci-fever; protozoal infection: Kala-azar.

2) Physico-chemical agents :

i) Physical agents : radium, Roentgen-rays, thorium $\mathbf{X}$, ionising radiation, etc.

ii) Chemical agents: benzol and its derivatives, e.g. anilin, amidopyrine, dinitrophenol, sulfon-amides, etc.; gold, arsenics, sarvarsan ; antithyroid drugs, e.g., thyouracil; anticancerous drugs: urethane, nitrogen mustards, nitromin, azaguanin, carcinophyllin; antimicrobial agents, e.g. chloramphenicol, antihistaminics.

3) Cachectic and debilitated states and inanition.

4) Disturbances of the liver, e.g. cirrhosis of liver; collagen diseases: Felty's syndrome, lupus erythematosus.

5) Hematopoietic disorders involving the spleen: Banti's disease, Gaucher's disease, pernicious anemia, agranulocytosis, aplastic anemia, aleukemia.

6) In anaphylactoid shock and in early stages of reaction to foreign protein.

Concerning the causative mechanism of leucocytosis and leucopenia many opinions have been uttered, while at the present time Naegeli's ${ }^{16}$ opinion is generally accepted. He regarded leucocytosis as an expression of sufficiency and leucopenia as that of insufficiency of the bone marrow.

In the studies of the principle of hematopoiesis in the bone marrow, the most important points to which particular attention should be paid are that 1) the bone marrow should be stimulated by a natural factor without artificial procedure so that they might be allowed to take their own natural courses, and that 2) the bone marrow function should be observed by systematic serial biopsies.

The stimulant factors to the bone marrow were only pathogenetic microbes in former times, but recently, by wonderful progress of physics and chemistry many physico-chemical agents were added thereto : that is, benzol was discovered by Farady ${ }^{12)}$ in 1825 ; X-rays, by Röntgen ${ }^{18)}$ in 1895 ; uranium, by Becquerel ${ }^{18}$ ) in 1896 and radium and thorium, by P. \& M. Curie ${ }^{20}$ in 1898.

Nowadays these physico-chemical agents are of great efficacy in making diagnosis as well as in treatments in medical practice. On the other hand, however, their sidereffects upon the viscerae, especially upon the bone marrow have 
come into question. In addition, atom-bomb was invented in 1945, whose terrible influence upon the bone marrow and sexual organs has called world-wide attention.

Yet the phylogenesis of Homosapiens in 50 myriad years has been the history of their struggle for survival against pathogenetic microbes, and the hematopoietic function in the bone marrow is an expression of an adaptation which is also attained in the course of struggle of mankind against them. Therefore, the principle of hematopoiesis in the bone marrow can be found in studying the course of infectious diseases.

\section{Hematopoietic Function of the Bone Marrow}

The bone marrow function was studied here in the course of infectious diseases allowed to take their own natural course, no antibiotics but only bone marrow puncture being applied.

The hematopoietic function of the bone marrow is divided into the formation of cells and their maturation; the former is related with the quantity of blood cells, the latter with their quality.

The appearance of basophilic stippling and anisocytosis of the erythrocytes, and those of Döhle's inclusion bodies and toxic granules of the leucocytes are regarded as due to the disturbance of the maturation function, but as it was, these findings are of little significance unless the bone marrow falls into insufficiency. On the contrary, the cell-formation function of the bone marrow is of great importance, both in hematology and in sero-immunology.

In general, the formation of blood cells depends upon mitosis. The mitosis of nucleated cells in the bone marrow was observed with the aid of Dr. Miyamoto after Rohr's ${ }^{21)}$ counting method and the mitosis index (M.I.) was calculated by following formula :

$$
\text { Mitosis index }\left(\%_{0}\right)=\frac{\text { mitosis count }}{\text { nucleated cell count }} \times 1,000
$$

1. Monophasis of Mitosis in the Erythropoietic System in the Bone Marrow

1) Mitosis in the erythropoietic system in the bone marrow of 5 normal subjects: the mitosis index of nucleated cells in the erythropoietic system is

Table I. Mitosis Index in Normal Cases

\begin{tabular}{|c|c|c|c|c|c|c|c|c|}
\hline \multirow{3}{*}{$\begin{array}{l}\text { Kind of } \\
\text { Cell }\end{array}$} & \multirow{2}{*}{\multicolumn{3}{|c|}{$\begin{array}{l}\text { Erythropoiesis } \\
\text { Erythroblasts }\end{array}$}} & \multicolumn{5}{|c|}{ Leucopoiesis } \\
\hline & & & & \multirow{2}{*}{$\begin{array}{l}\text { Myelo- } \\
\text { blasts }\end{array}$} & \multicolumn{3}{|c|}{ Neutrophil myelocytes } & \multirow{2}{*}{$\begin{array}{l}\text { Eosino- } \\
\text { phils }\end{array}$} \\
\hline & $\begin{array}{l}\text { Baso- } \\
\text { phil }\end{array}$ & $\begin{array}{l}\text { Poly- } \\
\text { chroma- } \\
\text { tic }\end{array}$ & Oxyphil & & $\begin{array}{l}\text { Un- } \\
\text { matured }\end{array}$ & $\begin{array}{l}\text { Half- } \\
\text { matured }\end{array}$ & Matured & \\
\hline Cell counts & 1660 & 7710 & 5460 & 670 & 1560 & 2990 & 4740 & 2450 \\
\hline Mitosis counts & 155 & 304 & 162 & 2 & 13 & 55 & 33 & 7 \\
\hline M.T. $\%$ & 93.3 & 39.3 & 29.2 & 2.99 & 8.33 & 18.39 & 0.98 & 2.81 \\
\hline
\end{tabular}


TABLE II. Frequency of

\begin{tabular}{|c|c|c|c|c|c|}
\hline \multicolumn{4}{|c|}{ Erythropoiesis } & \multicolumn{2}{|c|}{ Leucopoiesis } \\
\hline \multirow{2}{*}{$\underset{\%}{\text { M.I. }}$} & \multicolumn{3}{|c|}{ Erythroblasts } & \multirow{2}{*}{$\begin{array}{l}\text { M.I. } \\
\% 0\end{array}$} & \multirow{2}{*}{$\begin{array}{c}\text { Myeloblasts } \\
\%\end{array}$} \\
\hline & $\begin{array}{c}\text { Basophil } \\
\%\end{array}$ & $\begin{array}{l}\text { Polychro- } \\
\text { matic \% }\end{array}$ & Oxyphil & & \\
\hline $38.5 \sim 46.3$ & $18.6-33.2$ & $42.1-53.9$ & $12.9-39.3$ & $2.2 \sim 2.7$ & $0-4.3$ \\
\hline 41.84 & 24.04 & 48.44 & 27.52 & 2.40 & 1.60 \\
\hline
\end{tabular}

$41.84 \%$, and the highest one is $93.3 \%$ in basophil erythroblasts. $48.44 \%$ in polychromatic erythroblasts indicates the highest frequency of mitosis, as shown. in Tables I and II.

Table III shows the frequency of cells in the four phases in mitosis; the highest is $54.4 \%$ in prophase, followed by metaphase, telophase, anaphase in descending order.

Table III. Frequency of Every Mitosis-Phase in Normal Cases

\begin{tabular}{|c|c|c|c|c|c|c|c|c|}
\hline System & & $y$ thropoi & tic syster & & & Leucopoiet & ic system & \\
\hline Phase & Pro. & Meta. & Ana. & Telo. & Pro. & Meta. & Ana. & Telo. \\
\hline $\begin{array}{l}\text { Mean } \% \\
\text { value } \%\end{array}$ & \begin{tabular}{|c|}
$46.6-67.6$ \\
54.42
\end{tabular} & $8.8-22.9$ & $9.1-14.3$ & $11.8-18.2$ & $48.2-66.6$ & $12.5-25.8$ & $\begin{array}{c}4.6-14.8 \\
10.68\end{array}$ & $8.4-18.2$ \\
\hline
\end{tabular}

2) Mitosis in the erythropoietic system in the bone marrow in leucocytosis.

In 5 cases of leucocytosis ( 4 cases of Japanese encephalitis and 1 case of scarlet fever), the mitosis index in the erythropoietic system in the bone marrow in every stage of illness was observed. The mitosis index, as shown in Table IV, was $41.46 \%$ in the acme ; $42.45 \%$ in the fever-abating stage and $42.20 \%$ in the reconvalescence. In these cases, the erythrocyte count in the peripheral blood is 4.52 millions in the acme; 4.59 millions in the fever-abating stage and 4.78 millions in the reconvalescence. That is to say, unless anemia appeared in the peripheral

Table IV. Relation between Mitosis Index in the Erythropoietic System and the Red Blood Cell Count in the Peripheral Blood

in Every Stage of the Illness

\begin{tabular}{c|c|c|c|c|c|c}
\hline \multicolumn{1}{c|}{ Disease } & \multicolumn{3}{|c|}{ Leucocytosis } & \multicolumn{3}{c}{ Leucopenia } \\
\hline $\begin{array}{c}\text { Stage of the } \\
\text { illness }\end{array}$ & Acme & $\begin{array}{l}\text { Fever- } \\
\text { abating }\end{array}$ & Reconv. & Acme & $\begin{array}{c}\text { Fever- } \\
\text { abating }\end{array}$ & Reconv. \\
\hline M.I. \% & $38.7-47.0$ & $4.02-44.2$ & $38.2-47.2$ & $35.9-48.4$ & $35.5-50.5$ & $38.6-58.1$ \\
Mean value \% & 41.46 & 42.45 & 42.20 & 42.28 & 42.74 & 45.88 \\
$\begin{array}{c}\text { R.B.C. (Million) } \\
\text { Mean value } \\
\text { (Million) }\end{array}$ & $3.53-5.44$ & $3.88-5.39$ & $4.00-5.31$ & $2.64-4.15$ & $2.98-4.48$ & $3.66-4.72$ \\
& 4.52 & 4.59 & 4.78 & 3.35 & 3.85 & 4.33
\end{tabular}


Mitosis in Normal Cases

\begin{tabular}{c|c|c|c|c}
\hline \multicolumn{4}{c|}{ Leucopoiesis } & \\
\hline \multicolumn{3}{c}{ Neutrophil myelocytes } & & Eosinophils \\
\hline $\begin{array}{c}\text { Unmatured } \\
\%\end{array}$ & $\begin{array}{c}\text { Half-matured } \\
\%\end{array}$ & $\begin{array}{c}\text { Matured } \\
\%\end{array}$ & Meta-myelocytes & $\%$ \\
\hline $4.6-16.6$ & $39.2-58.2$ & $25.0-54.6$ & 0 & $0-13.1$ \\
10.80 & 45.74 & 36.08 & 0 & 5.78
\end{tabular}

blood, the mitosis index in erythropoietic system in the bone marrow showed nearly $42 \%$ of its normal value. Table $\mathrm{V}$ shows the mitosis index in various kinds of erythroblasts in every stage of illness; the mitosis index showed the highest value of $52.7 \%$ in polychromatic erythroblasts in the acme, and returned to the normal value after the fever-abating stage.

Table V. Mitosis Index in Various Kinds of Cells in the Erythropoietic System in Every Stage of the Illness

\begin{tabular}{|c|c|c|c|c|c|c|c|}
\hline \multirow{2}{*}{$\frac{\text { Disease }}{\text { Stage }}$} & & \multicolumn{3}{|c|}{ Leucocytosis } & \multicolumn{3}{|c|}{ Leucopenia } \\
\hline & $\begin{array}{r}\text { Kind of } \\
\text { Cell }\end{array}$ & Basophil & $\begin{array}{l}\text { Polychro- } \\
\text { matic }\end{array}$ & Oxyphil & Basophil & $\begin{array}{l}\text { Polychro- } \\
\text { matic }\end{array}$ & Oxyphil \\
\hline \multirow{3}{*}{ Acme } & Cell counts & 1,187 & 3,770 & 3,602 & 1,036 & 2,740 & 5,108 \\
\hline & Mitosis counts & 62 & 119 & 90 & 93 & 137 & 130 \\
\hline & M.I. $\%$ & 52.3 & 52.7 & 24.9 & 89.7 & 50.0 & 25.6 \\
\hline \multirow{3}{*}{$\begin{array}{l}\text { Fever- } \\
\text { abating }\end{array}$} & Cell counts & 578 & 2,294 & 1,238 & 1,456 & 3,710 & 3,912 \\
\hline & Mitosis counts & 34 & 102 & 38 & 108 & 192 & 144 \\
\hline & M.I. $\%$ & 59.0 & 47.2 & 30.8 & 74.1 & 54.4 & 29.3 \\
\hline \multirow{3}{*}{$\begin{array}{l}\text { Reconva } \\
\text { lescence }\end{array}$} & Cell counts & 1,374 & 3,396 & 4,310 & 1,139 & 3,740 & 4,368 \\
\hline & Mitosis counts & 79 & 187 & 113 & 92 & 214 & 136 \\
\hline & M.I. \% & 57.4 & 55.2 & 62.2 & 80.7 & 57.2 & 31.0 \\
\hline
\end{tabular}

In respect of the frequency of mitosis in every stage of the illness, polychromatic erythroblasts occupied the highest position throughout the entire course. And the frequency of four phases of mitosis in the erythropoietic system was similar to that in normal subjects, as shown in Table VI.

TABLE VI. Frequency of Motisis in the Erythropoietic System in Every Stage of the Illness (\%)

\begin{tabular}{l|c|c|c|c|c|c}
\hline \multicolumn{1}{c|}{ Disease } & \multicolumn{3}{|c|}{ Leucocytosis } & \multicolumn{3}{c}{ Leucopenia } \\
\cline { 1 - 5 } Kind of Cell & Basophil & $\begin{array}{l}\text { Polychro- } \\
\text { matic }\end{array}$ & Oxyphil & Basophil & $\begin{array}{l}\text { Polychro- } \\
\text { matic }\end{array}$ & Oxyphil \\
Stage & 17.8 & 56.6 & 25.6 & 25.8 & 38.1 & 36.1 \\
\hline Acme & 19.5 & 58.7 & 21.8 & 24.4 & 43.4 & 32.2 \\
Fever-abating & 20.8 & 49.4 & 29.8 & 20.8 & 48.5 & 30.7 \\
Reconvalescence & & & &
\end{tabular}


3) Mitosis in the erythropoietic system in the bone marrow in leucopenia.

In 5 cases of leucopenia ( 3 cases of typhoid and 2 cases of paratyphoid A), mitosis index in the erythropoietic system in the bone marrow was observed: the mitosis index was $42.28 \%$ in the acme ; $42.74 \%$ in the fever-abating stage and $45.88 \%$ in the reconvalescence, as shown in Table IV. At the same time, the erythrocyte count amounted to 3.35 millions in the acme stage; to 3.85 millions in the fever-abating stage and to 4.33 millions in the reconvalescent stage. These are significant in showing that the mitosis index was hightened in the course of illness when anemia appeared in the peripheral blood.

The mitosis index showed the highest value of $89.7 \%$ in basophil erythroblasts through the entire course of illness, as shown in Table V. And the frequency of mitosis in polychromatic erythroblasts showed the highest percentage in every stage of the illness (Table VI). Among the four phases of mitosis in the erythropoietic system, the prophase showed the highest frequency through the entire course, and the frequency was similar to that seen in normal subjects (Table VII).

TABLE VII. Frequency of Every Mitosis-Phase in the Erythropoietic System (\%)

\begin{tabular}{|c|c|c|c|c|c|c|c|c|}
\hline Disease & \multicolumn{4}{|c|}{ Leveocytosis } & \multicolumn{4}{|c|}{ Leucopenia } \\
\hline Phase & Pro. & Meta. & Ana. & Telo. & Pro. & Meta. & Ana. & Telo. \\
\hline Acme & 39.2 & 19.1 & 13.5 & 28.2 & 37.7 & 23.9 & 14.3 & 24.1 \\
\hline Fever-abating & 41.6 & 25.3 & 12.6 & 20.5 & 44.6 & 25.2 & 12.6 & 17.6 \\
\hline Reconvalescence & 39.1 & 20.3 & 14.0 & 26.6 & 44.4 & 21.2 & 14.5 & 19.9 \\
\hline
\end{tabular}

As observed above, the mitosis in the erythropoietic system in the bone marrow shows nothing characteristic either in leucocytosis or leucopenia, as compared with that in normal subjects. But, when anemia occurs in the peripheral blood, $\mathrm{CO}_{2}$ concentration is elevated in the body and the latter acts as a stimulant factor upon the bone marrow, raising mitosis in the erythropoietic system in the bone marrow. The rise of mitosis is at first on the left, later gradually on the right in the bone marrow and the erythrocytes increase gradually to the normal value. Therefore, it can be recognized that the erythrocytes are formed in the monophasis in the bone marrow, so long as it is insufficiency.

2. Diphasis of Mitosis in the Leucopoietic System in the Bone Marrow

A. 2 trends of mitosis in the lencopoietic system in the bone marrow.

1) Mitosis in the leucopoietic system in the bone marrow of normal subjects. In the leucopoietic system in the bone marrow of above-mentioned 5 
normal subjects, the mitosis index of the nucleated cells is $2.4 \%$. The mitosis index of the half-matured myelocytes shows the highest value of $18.39 \%$ (Table I) and the frequency of mitosis of the half-matured myelocytes the highest of $45.74 \%$ (Table II).

The frequency of the four phases of mitosis, as shown in Table III, rises to the highest value of $55.12 \%$ in the prophase and next in the metaphase, telophase and anaphase in the order named.

2) Mitosis in the leucopoietic system in the bone marrow in leucocytosis.

In the 5 cases of leucocytosis above mentioned, the mitosis index in the leucopoietic system amounted to $3.28 \%$ in the peak stage, being apparently more heightened than in normal cases. It is obviously lowered to the somewhat subnormal height of $2.30 \%$ in the fever-abating stage, but rose again in the reconvalescence, showing almost normal value of $2.58 \%$. On the other hand, the leucocyte count in peripheral blood was 11,440 in the peak stage, 9,400 in the fever abating stage and 8,360 in the reconvalescence (Table VIII).

TABLE VIII. Relation between the Mitosis Index in the Leucopoietic System and the White Blood Cell Count in the Peripheral

Blood in Every Stage of the Illness

\begin{tabular}{l|c|c|c|c|c|c}
\hline \multirow{2}{*}{ Disease } & \multicolumn{3}{|c|}{ Leucocytosis } & \multicolumn{3}{c}{ Leucopenia } \\
\cline { 2 - 6 } Stage & Acme & $\begin{array}{c}\text { Fever- } \\
\text { abating }\end{array}$ & Reconv. & Acme & $\begin{array}{l}\text { Fever- } \\
\text { abating }\end{array}$ & Reconv. \\
\hline M.I. \%o & $2.6-4.3$ & $1.8-3.2$ & $1.8-3.3$ & $1.6-2.4$ & $1.7-3.8$ & $2.1-2.4$ \\
Mean value \% & 3.28 & 2.30 & 2.58 & 1.94 & 2.52 & 2.26 \\
W.B.C. & $9,400-$ & $7,400-$ & $7,000-$ & $2,600-$ & $2,500-$ & $3,300-$ \\
Mean value & 13,300 & 12,000 & 9,700 & 7,000 & 6,300 & 6,800 \\
& 11,440 & 9,400 & 8,360 & 4,000 & 4,840 & 5,540
\end{tabular}

Table IX shows the mitosis index in various kinds of the nucleated cells in the leucopoietic system in the bone marrow; mitosis is strikingly accelerated in various kinds of cells and the mitosis index of matured myelocytes rises remarkably in the peak stage, but thereafter mitosis gradually slows down and the mitosis index of unmatured myelocytes shows the highest value in the course of illness as in normal subjects. The frequency of mitosis in every stage of the illness, as shown in Table $X$, shows the highest percentage of $43.0 \%$ in the matured myelocytes and in the later course of the illness, the center of mitosis, shifting from right to left in the bone marrow, returned to the normal.

In the frequency of four phases of mitosis in the leucopoietic system, no great difference is there between leucocytosis cases and normal cases, as shown in Table XI.

3) Mitosis in the leucopoietic system in the bone marrow of leucopenia.

In the 5 cases of leucopenia mentioned above, the mitosis index in the 
A. Saito

TABLE IX. Mitosis Index in Various Kinds of Cells in

\begin{tabular}{|c|c|c|c|c|c|}
\hline \multicolumn{2}{|c|}{ Disease } & \multicolumn{4}{|c|}{ Leucocy tosis } \\
\hline \multirow{2}{*}{ Stage } & \multirow{2}{*}{ Kind of cell } & \multirow{2}{*}{ Myeloblasts } & \multicolumn{3}{|c|}{ Myelocytes } \\
\hline & & & Unmatured & Half-matured & Matured \\
\hline \multirow{3}{*}{ Acme } & Cell counts & 607 & 1,175 & 2,152 & 4,227 \\
\hline & M. counts & 9 & 23 & 58 & 71 \\
\hline & M.I. $\%$ & 14.8 & 19.6 & 26.9 & 16.9 \\
\hline \multirow{3}{*}{$\begin{array}{l}\text { Fever- } \\
\text { abating }\end{array}$} & Cell counts & 378 & 914 & 1,690 & 2,478 \\
\hline & M. counts & 2 & 14 & 32 & 30 \\
\hline & M.I. $\%$ & 5.4 & 15.2 & 19.0 & 12.2 \\
\hline \multirow{3}{*}{$\begin{array}{l}\text { Reconva- } \\
\text { lescence }\end{array}$} & Cell counts & 773 & 1,215 & 2,294 & 4,079 \\
\hline & M. counts & 5 & 25 & 59 & 43 \\
\hline & M.I. \% $\%$ & 6.5 & 20.5 & 25.8 & 10.5 \\
\hline
\end{tabular}

TABLE X. Frequency of Mitosis in the Leucopoietic System

\begin{tabular}{c|c|c|c|c|c|c|}
\hline \multirow{2}{*}{$\begin{array}{c}\text { Kind of } \\
\text { Cell }\end{array}$} & $\begin{array}{c}\text { Myelo- } \\
\text { blasts }\end{array}$ & \multicolumn{3}{|c|}{ Leucocytosis } & Metacytes \\
\cline { 3 - 7 } & Unmatured & Half-matured & Matured & Eosinophils \\
\hline Acme & 5.4 & 14.0 & 35.2 & 43.0 & 0 & 2.4 \\
$\begin{array}{c}\text { Fever- } \\
\text { abating }\end{array}$ & 2.2 & 15.6 & 35.6 & 33.3 & 0 & 13.3 \\
$\begin{array}{c}\text { Reconva- } \\
\text { lescence }\end{array}$ & 3.9 & 15.9 & 37.6 & 27.4 & 0 & 15.9
\end{tabular}

TABLE XI. Frequency of Every Mitosis-Phase in the Leucopoietic System $(\%)$

\begin{tabular}{l|r|r|r|r|r|r|r|r}
\hline \multicolumn{1}{c|}{ Disease } & \multicolumn{3}{|c|}{ Leucocytosis } & \multicolumn{4}{c}{ Leucopenia } \\
\cline { 3 - 8 } Phase & Proc. & Meta. & Ana. & Telo. & Pro. & Meta. & Ana. & Telo. \\
\hline Acme & 57.6 & 17.0 & 17.5 & 7.9 & 22.5 & 42.8 & 27.6 & 7.1 \\
Fever-abating & 55.5 & 6.7 & 6.7 & 17.8 & 38.7 & 33.9 & 16.2 & 11.2 \\
Reconvalescence & 51.7 & 15.3 & 15.3 & 8.9 & 57.2 & 25.0 & 14.3 & 3.5
\end{tabular}

leucopoietic system was $1.94 \%$ in the peak stage, $2.52 \%$ in the fever-abating stage and $2.26 \%$ in the reconvalescence, as presented in Table VIII. On the other hand, the leucocyte count in the peripheral blood is 4400 in the peak stage, 4840 in the fever-abating stage and 5540 in the reconvalescence. Table IX shows the mitosis index of various kinds of the nucleated cells in the leucopoietic system in every stage of the illness; the mitosis index was lowered in the half-matured myelocytes, particularly in the matured myelocytes in the 
the Leucopoietic System in Every Stage of the Illness

\begin{tabular}{c|c|c|c|c|c}
\hline & \multicolumn{5}{|c|}{ Leucopenia } \\
\cline { 2 - 6 } Eosinophils & \multirow{2}{*}{ Myeloblasts } & \multicolumn{3}{|c}{ Myelocytes } & Eosinophils \\
\cline { 2 - 6 } & & Unmatured & Half-matured & Matured & \\
\hline 2,602 & 580 & 853 & 1,687 & 4,118 & 1,389 \\
4 & 5 & 17 & 35 & 37 & 4 \\
1.5 & 8.6 & 19.9 & 20.6 & 9.1 & 2.8 \\
\hline 1,592 & 428 & 1,242 & 1,708 & 3,978 & 992 \\
12 & 6 & 20 & 50 & 44 & 4 \\
7.6 & 14.0 & 16.0 & 29.2 & 11.0 & 4.0 \\
\hline 6,111 & 446 & 932 & 1,636 & 3,526 & 1,266 \\
25 & 4 & 30 & 50 & 40 & 4 \\
4.1 & 9.0 & 32.2 & 30.6 & 12.6 &
\end{tabular}

in Every Stage of the Illness (\%)

\begin{tabular}{|c|c|c|c|c|c|}
\hline \multicolumn{6}{|c|}{ Leucopenia } \\
\hline \multirow{2}{*}{ Myeloblasts } & \multicolumn{3}{|c|}{ Myelocytes } & \multirow{2}{*}{$\begin{array}{l}\text { Metamyelo- } \\
\text { cytes }\end{array}$} & \multirow{2}{*}{ Eosinophils } \\
\hline & Unmatured & Half-matured & Matured & & \\
\hline 5.6 & 17.4 & 35.7 & 37.8 & 0 & 3.5 \\
\hline 4.8 & 16.2 & 40.3 & 35.4 & 0 & 3.3 \\
\hline 1.7 & 23.2 & 39.3 & 32.2 & 0 & 3.6 \\
\hline
\end{tabular}

peak stage, but after the fever-abating stage rose gradually from left to right in the bone marrow and then returned to normal. The frequency of mitosis showed the highest percentage of $37.8 \%$ in matured myelocytes in the peak stage ; of $40.3 \%$ in half-matured myelocytes in the fever-abating stage, as shown in Table X.

The frequency of four phases of mitosis showed the highest percentage in the metaphase in the peak stage, but after the fever-abating stage its highest percentage was shown in the prophase, as in normal subjects (Table XI). Table

TABLE XII. Relation between Mitosis Index and the White Blood Cell Count in the Peripheral Blood

\begin{tabular}{l|c|c|c}
\hline W.B.C. & $2,001-6,000$ & $6,001-9,000$ & $9,001-13,000$ \\
\hline Disease & Leucopenia & Normal & Leucocytosis \\
\hline M.I. \%o & $1.90-2.38$ & $2.20-3.10$ & $2.60-4.30$ \\
Mean value \%o & 2.17 & 2.50 & 3.20
\end{tabular}


XII shows the relation between mitosis index in the leucopoietic system in the bone marrow and the leucocyte count in the peripheral blood.

4) Mitosis in the Reticuloendothelial System in the Bone Marrow.

Throughout the entire course of leucocytosis, the mitosis index in the reticuloendothelial system rose to the height of $2.16 \%$ in the peak stage showing a supernormal value, but in leucopenia showed almost normal value of $1 \%$ (Table XIII).

TABLE XIII. Mitosis Index in the Reticuloendothelial System in Every Stage of the Illness

\begin{tabular}{l|r|r|r|r|r|r}
\hline \multicolumn{1}{c|}{ Disease } & \multicolumn{3}{|c|}{ Leucocytosis } & \multicolumn{3}{c}{ Leucopenia } \\
\cline { 2 - 7 } $\begin{array}{c}\text { Stage of the } \\
\text { illness }\end{array}$ & Acme & $\begin{array}{l}\text { Fever- } \\
\text { abating }\end{array}$ & Reconv. & Acme & $\begin{array}{l}\text { Fever- } \\
\text { abating }\end{array}$ & Reconv. \\
\hline M.I. \% $\%$ & $0-4.5$ & $0-3.2$ & $0-3.5$ & $0-2.0$ & $0-2.9$ & $0-2.4$ \\
Mean value $\%$ & 2.16 & 1.32 & 1.45 & 1.08 & 0.98 & 1.24
\end{tabular}

Rising or lowering of mitosis in the bone marrow shows increase or decrease of the nucleated cells in the bone marrow; that is to say, the bone marrow was rich in nucleated cells in the cases of leucocytosis, while it was poor in them in the cases of leucopenia (Tables XIV and XV).

Accordingly, the nucleated cell count in the former not rarely reached the level almost twice or thrice as high as in the latter. Thus, the author has found that the mitosis index tends toward rising in the cases of leucocytosis, while in the cases of leucopenia tends toward lowering, the mitosis index attaining the normal level after the reconvalescence in both cases.

B. Diphasis of mitosis in the leucopoietic system in the bone marrow.

The author inquired into the two trends of mitosis in the leucopoietic system in the bone marrow. According to the leucocyte counts of the cases, all the infectious diseases can be divided into two groups: those accompanying leucocytosis and those with leucopenia. From the angle of genetic mechanism, the difference between the two originates in their mitotic function in the bone marrow; namely, it is plainly raised in leucocytosis, while it is plainly lowered in leucopenia.

The values of mitosis index in every stage of leucocytosis and leucopenia are marked with point co-ordinates, setting the axis of the co-ordinates at the level of $2.4 \%$ of normal mitosis index : $3.28 \%$ in the acme, $2.30 \%$ in the feverabating stage and $2.58 \%$ in the reconvalescence of leucocytosis; in the same way, $1.94 \%$ in the acme, $2.52 \%$ in the fever-abating stage and $2.26 \%$ in the reconvalescence of leucopenia. When traced successively, these points present a pair of wavy curves shown in thick lines in Fig. 1.

When these curves are corrected on the basis of outflows of leucocytes into 


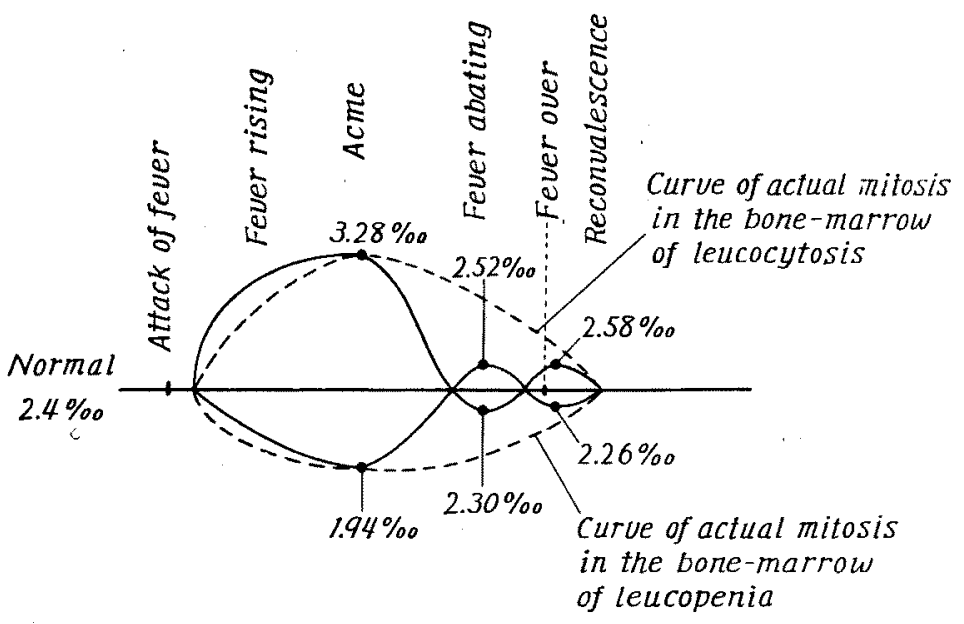

Fig. 1. Curves of mitosis index of leucopoietic system in the bone marrow in the course of leucocytosis and leucopenia.

the peripheral blood and on the basis of changes of the nucleated cell count in the bone marrow, they can be shown as a pair of simple symmetric curves (dotted curves) with trends toward rising and lowering respectively, and they indicate the actual mitosis in the leucopoietic system in the bone marrow of leucocytosis and leucopenia.

After six years of contemplation of these experimental results, the conception of phases was at last acquired. If the pair of these curves be taken to represent the 2 trends in one and the same phase, the downward trend is naturally to be considered as showing an insufficiency of the bone marrow; while on the contrary, if it be taken to show the 2 peculiar trends in 2 phases respectively, then the downward trending is to be considered not as indicating an insufficiency but a sufficiency of the bone marrow, namely, a peculiar trend of mitosis which appears when the bone marrow is stimulated.

Which of the two interpretation of the pair of these curves is the right one ? Seeing the specificity of pathogenetic factors described below, it is clear that the latter is the right one.

Here the author has named the upward mitotic course the first phase, and the downward mitotic course the second phase; also the factors active in the former the first-phase factors, and these in the latter the second-phase factors. Accordingly, the specificity among the factors not merely in the different phases but also in the same phase can be recognized regularly and definitely.

Thus both in the first- and second- phase the normal bone marrow is stimulated by the pathogenetic microbes, and reacts physicologically against them according to the specificities of their factors.

It is, therefore, improper simply to take increase of the white blood cells 
Table XIV. Frequency of Every Phase

\begin{tabular}{|c|c|c|c|c|c|c|c|c|c|c|}
\hline $\begin{array}{l}\text { Name } \\
\text { Age } \\
\text { Sex }\end{array}$ & Disease & Stage & 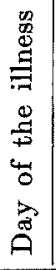 & 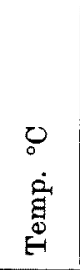 & $\begin{array}{l}20 \\
0 \\
20 \\
11\end{array}$ & 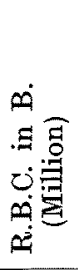 & $\begin{array}{l}\dot{0} \\
.9 \\
0 \\
\dot{0} \\
\dot{B}\end{array}$ & $\begin{array}{l}\text { Nucleated } \\
\text { cells in } \\
\text { B.M. }\end{array}$ & \multicolumn{2}{|c|}{$\begin{array}{l}\text { Counted } \\
\text { cells }\end{array}$} \\
\hline $\begin{array}{c}\text { E. Y. } \\
18 \\
\text { years old } \\
\delta\end{array}$ & $\begin{array}{c}\text { Enceph. } \\
\text { jap. }\end{array}$ & $\begin{array}{l}\text { Acme } \\
\text { Fever- } \\
\text { abating } \\
\text { Reconv. }\end{array}$ & 25 & $\begin{array}{r}39.9 \\
37.4 \\
36.8\end{array}$ & 83 & $\begin{array}{l}3.53 \\
4.21 \\
4.00\end{array}$ & $\begin{array}{r}12200 \\
9000 \\
9700\end{array}$ & $\begin{array}{r}199000 \\
237000\end{array}$ & $\begin{array}{c}\text { Ret } \\
\mathbf{R} \\
W \\
\text { Ret } \\
\mathbf{R} \\
W \\
\text { Ret } \\
\mathbf{R} \\
W\end{array}$ & $\begin{array}{r}526 \\
2134 \\
10000 \\
286 \\
1070 \\
10000 \\
382 \\
2220 \\
10000\end{array}$ \\
\hline $\begin{array}{c}\text { M. Y. } \\
5 \mathrm{Y} .10 \mathrm{M} . \\
\delta\end{array}$ & $\begin{array}{c}\text { Enceph. } \\
\text { jap. }\end{array}$ & 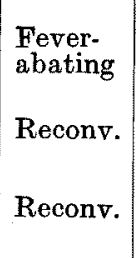 & 25 & $\begin{array}{l}37.4 \\
37.1 \\
36.5\end{array}$ & $\begin{array}{l}80 \\
86\end{array}$ & \begin{tabular}{r|}
3.88 \\
4.89 \\
5.31
\end{tabular} & $\begin{array}{r}7400 \\
7000 \\
9500\end{array}$ & $\begin{array}{r}351200 \\
181000 \\
298000\end{array}$ & $\begin{array}{c}\text { Ret } \\
\mathbf{R} \\
W \\
\text { Ret } \\
\mathbf{R} \\
\mathbf{W} \\
\mathbf{R e t} \\
\mathbf{R} \\
\mathbf{W}\end{array}$ & $\begin{array}{r}301 \\
794 \\
10000 \\
280 \\
1966 \\
10000 \\
402 \\
1544 \\
10000\end{array}$ \\
\hline $\begin{array}{c}\mathrm{S} . \mathrm{K} . \\
8 \mathrm{~J} \\
\text { years old } \\
\delta\end{array}$ & $\begin{array}{c}\text { Enceph. } \\
\text { jap. }\end{array}$ & $\begin{array}{l}\text { Acme } \\
\text { Fever- } \\
\text { abating } \\
\text { Reconv. }\end{array}$ & 26 & $\begin{array}{r}38.6 \\
38.0 \\
37.1\end{array}$ & 92 & $\begin{array}{r}5.44 \\
5.39 \\
4.95\end{array}$ & $\begin{array}{r}13300 \\
9200 \\
8800\end{array}$ & $\begin{array}{r}91000 \\
99300 \\
142300\end{array}$ & $\begin{array}{c}\text { Ret } \\
R \\
W \\
\text { Ret } \\
R \\
W \\
\text { Ret } \\
R \\
\text { W }\end{array}$ & $\begin{array}{r}437 \\
817 \\
10000 \\
594 \\
890 \\
10000 \\
866 \\
1430 \\
10000\end{array}$ \\
\hline $\begin{array}{c}\text { S. T. } \\
19 \\
\text { years old } \\
\&\end{array}$ & $\begin{array}{c}\text { Enceph. } \\
\text { jap. }\end{array}$ & $\begin{array}{l}\text { Acme } \\
\text { Acme } \\
\text { Fever- } \\
\text { abating }\end{array}$ & 55 & \begin{tabular}{r|}
38.1 \\
37.9 \\
37.6
\end{tabular} & $\begin{array}{l}90 \\
89\end{array}$ & $\begin{array}{r}4.75 \\
4.15 \\
4.89\end{array}$ & $\begin{array}{r}9400 \\
12200 \\
12000\end{array}$ & $\begin{array}{r}138400 \\
162000 \\
127400\end{array}$ & $\begin{array}{c}\text { Ret } \\
R \\
W \\
\text { Ret } \\
R \\
\underset{W}{\text { Ret }} \\
\text { Ret } \\
\mathbb{R} \\
W\end{array}$ & $\begin{array}{r}588 \\
2004 \\
10000 \\
690 \\
2326 \\
10000 \\
472 \\
1356 \\
10000\end{array}$ \\
\hline $\begin{array}{c}\text { S. T. } \\
6 \\
\text { years old } \\
q\end{array}$ & $\begin{array}{l}\text { Scarlet } \\
\text { fever }\end{array}$ & $\begin{array}{l}\text { Acme } \\
\text { Reconv. } \\
\text { Reconv. }\end{array}$ & 16 & \begin{tabular}{l|}
36.7 \\
36.4
\end{tabular} & 87 & 4.68 & $\begin{array}{r}10100 \\
8200 \\
8000\end{array}$ & $\begin{array}{r}125000 \\
157000 \\
88000\end{array}$ & $\begin{array}{c}\text { Ret } \\
\mathbf{R} \\
\mathbf{W} \\
\mathbf{R e t} \\
\mathbf{R} \\
\mathbf{W} \\
\mathbf{R e t} \\
\mathbf{R} \\
\mathbf{W}\end{array}$ & $\begin{array}{r}478 \\
1278 \\
10000 \\
406 \\
1412 \\
10000 \\
360 \\
508 \\
10000\end{array}$ \\
\hline
\end{tabular}


of the Mitosis in Leucocytosis

\begin{tabular}{|c|c|c|c|c|c|c|c|c|c|c|c|c|c|c|c|c|c|c|}
\hline \multirow[b]{3}{*}{$\begin{array}{l}\stackrel{0}{+} \\
\stackrel{\Xi}{\Xi} \\
8 \\
\dot{8}\end{array}$} & \multirow[b]{3}{*}{$\begin{array}{l}8 \\
2 \\
2 \\
2\end{array}$} & \multicolumn{17}{|c|}{ Appearance of mitosis } \\
\hline & & \multicolumn{7}{|c|}{ Erythropoiesis } & \multicolumn{10}{|c|}{ Leucopoiesis } \\
\hline & & 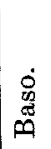 & $\frac{\dot{d}}{0}$ & $\overrightarrow{0}$ & 定 & 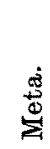 & 毞 & $\frac{\dot{\theta}}{\mathscr{Q}}$ & 릴 & 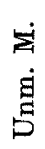 & 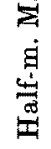 & 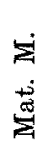 & 空 & $\dot{0}$ & $\stackrel{0}{0}$ & 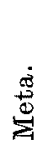 & $\tilde{E}_{\text {है }}$ & $\frac{\dot{0}}{0}$ \\
\hline $\begin{array}{r}0 \\
84 \\
26 \\
0\end{array}$ & $\begin{array}{c}0 \\
39.3 \\
2.6 \\
0\end{array}$ & 20 & 52 & 12 & 34 & 24 & 12 & 14 & 2 & 4 & 10 & 8 & 0 & 2 & 16 & 6 & 4 & 0 \\
\hline $\begin{array}{r}42 \\
32 \\
0\end{array}$ & $\begin{array}{c}42.3 \\
3.2 \\
0\end{array}$ & 12 & 22 & 8 & 20 & 8 & 6 & 8 & 0 & 6 & 10 & 10 & 0 & 6 & 20 & 6 & 0 & 6 \\
\hline $\begin{array}{l}92 \\
33\end{array}$ & $\begin{array}{r}41.6 \\
3.3\end{array}$ & 14 & 40 & 38 & 36 & 24 & 12 & 20 & 0 & 6 & 12 & 8 & 0 & 8 & 16 & 8 & 6 & 4 \\
\hline $\begin{array}{r}0 \\
34 \\
18 \\
1\end{array}$ & $\begin{array}{r}0 \\
42.7 \\
1.8 \\
3.5\end{array}$ & 10 & 18 & 6 & 14 & 12 & 4 & 4 & $\mathbf{0}$ & 2 & 6 & 8 & 0 & 2 & 10 & 4 & 0 & 4 \\
\hline $\begin{array}{l}86 \\
24\end{array}$ & $\begin{array}{r}43.7 \\
2.4\end{array}$ & 24 & 46 & 16 & 30 & 20 & 8 & 28 & 2 & 4 & 8 & 4 & 0 & 6 & 12 & 6 & 4 & 2 \\
\hline $\begin{array}{l}66 \\
33\end{array}$ & $\begin{array}{r}42.7 \\
3.3\end{array}$ & 16 & 32 & 18 & 28 & 16 & 10 & 12 & 2 & 4 & 10 & 10 & 0 & 8 & 20 & 8 & 6 & 0 \\
\hline $\begin{array}{r}\mathbf{2} \\
\mathbf{3 3} \\
27 \\
2\end{array}$ & $\begin{array}{r}4.5 \\
40.4 \\
2.7 \\
3.2\end{array}$ & 2 & 13 & 18 & 20 & $\mathbf{3}$ & 3 & 7 & 1 & 5 & 10 & 11 & 0 & 0 & 13 & 6 & 5 & 3 \\
\hline $\begin{array}{l}38 \\
19\end{array}$ & $\begin{array}{r}42.7 \\
1.9\end{array}$ & 4 & 24 & 10 & 16 & 12 & 4 & 6 & 0 & 2 & 8 & 8 & 0 & 0 & 8 & 4 & 4 & 2 \\
\hline $\begin{array}{l}57 \\
25\end{array}$ & $\begin{array}{r}39.8 \\
2.5\end{array}$ & 11 & 29 & 17 & 20 & 6 & 11 & 20 & 1 & 3 & 13 & 5 & 0 & 3 & 13 & 8 & 2 & 2 \\
\hline $\begin{array}{r}2 \\
84 \\
39\end{array}$ & $\begin{array}{r}3.4 \\
41.9 \\
3.9\end{array}$ & 12 & 46 & 26 & 18 & 12 & 18 & 36 & 4 & 4 & 12 & 20 & 0 & 0 & 22 & 8 & 6 & 4 \\
\hline $\begin{array}{l}2 \\
90 \\
29\end{array}$ & $\begin{array}{r}2.9 \\
38.7 \\
2.9\end{array}$ & 20 & 52 & 18 & 40 & 20 & 8 & 22 & 2 & 2 & 14 & 8 & 0 & 2 & 16 & 4 & 6 & 2 \\
\hline $\begin{array}{r}1 \\
60 \\
23\end{array}$ & $\begin{array}{r}2.1 \\
44.2 \\
2.3\end{array}$ & 8 & 38 & 14 & 22 & 12 & 8 & 18 & 2 & 4 & 8 & 4 & 0 & 4 & 12 & 4 & 2 & 4 \\
\hline $\begin{array}{r}0 \\
67 \\
43\end{array}$ & \begin{tabular}{c}
\multicolumn{1}{c}{${ }^{2}$} \\
47.0
\end{tabular} & 8 & 36 & 16 & 24 & 10 & 6 & 20 & 0 & 8 & 12 & 24 & 0 & 0 & 28 & 4 & 8 & 4 \\
\hline $\begin{array}{r}0 \\
54 \\
18 \\
18\end{array}$ & $\begin{array}{r}0 \\
38.2 \\
1.8 \\
2.7\end{array}$ & 8 & 28 & 18 & 26 & 6 & 6 & 16 & 0 & 4 & 6 & 8 & 0 & 0 & 8 & 4 & 4 & 2 \\
\hline $\begin{array}{l}24 \\
22\end{array}$ & $\begin{array}{r}37.2 \\
2.2\end{array}$ & 6 & 12 & 6 & 8 & 6 & 6 & 4 & 0 & 4 & 10 & 8 & 0 & 0 & 12 & 4 & 2 & 4 \\
\hline
\end{tabular}


TaBLE XV. Frequency of Every Phase

\begin{tabular}{|c|c|c|c|c|c|c|c|c|c|c|}
\hline $\begin{array}{l}\text { Name } \\
\text { Age } \\
\text { Sex }\end{array}$ & Disease & Stage & 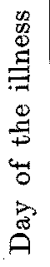 & $\begin{array}{l}0 \\
\dot{\varepsilon} \\
\dot{E} \\
E-1\end{array}$ & $\begin{array}{l}0 \\
\frac{0}{80} \\
11\end{array}$ & 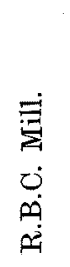 & $\begin{array}{l}\dot{n} \\
. \equiv \\
\dot{0} \\
\dot{0} \\
\dot{n}\end{array}$ & $\begin{array}{l}\text { Nucleated } \\
\text { cells } \\
\text { in B. M. }\end{array}$ & \multicolumn{2}{|c|}{$\begin{array}{l}\text { Counted } \\
\text { cells }\end{array}$} \\
\hline $\begin{array}{c}\text { S. S. } \\
27 \\
\text { years old } \\
9\end{array}$ & $\begin{array}{l}\text { Para- } \\
\text { typhoid } \\
\text { A }\end{array}$ & $\begin{array}{l}\text { Acme } \\
\text { Fever- } \\
\text { abating } \\
\text { Reconv. }\end{array}$ & $\begin{array}{l}27 \\
41\end{array}$ & $\begin{array}{r}38.9 \\
37.1 \\
36.7\end{array}$ & $\begin{array}{l}78 \\
70\end{array}$ & $\begin{array}{r}3.12 \\
3.68 \\
\\
3.66\end{array}$ & $\begin{array}{l}4000 \\
5400 \\
6200\end{array}$ & $\begin{array}{l}112000 \\
105000 \\
95000\end{array}$ & $\begin{array}{c}\text { Ret } \\
\mathbf{R} \\
W \\
\text { Ret } \\
\mathbf{R} \\
W \\
\text { Ret } \\
\mathbf{R} \\
\mathbf{W}\end{array}$ & $\begin{array}{r}674 \\
536 \\
10000 \\
362 \\
1072 \\
10000 \\
642 \\
1902 \\
10000\end{array}$ \\
\hline $\begin{array}{c}\text { M. M. } \\
25 \\
\text { years old } \\
q\end{array}$ & $\begin{array}{l}\text { Para- } \\
\text { typhoid } \\
\text { A }\end{array}$ & $\begin{array}{l}\text { Acme } \\
\text { Fever- } \\
\text { abating } \\
\text { Reconv. }\end{array}$ & $\begin{array}{l}26 \\
33\end{array}$ & $\begin{array}{r}38.8 \\
38.2 \\
36.3\end{array}$ & $\begin{array}{l}79 \\
81\end{array}$ & $\begin{array}{r}3.70 \\
3.89 \\
4.14\end{array}$ & $\begin{array}{l}5200 \\
5200 \\
5600\end{array}$ & $\begin{array}{l}180000 \\
135000 \\
144000\end{array}$ & $\begin{array}{c}\text { Ret } \\
\mathbf{R} \\
\mathbf{W} \\
\text { Ret } \\
\mathbf{R} \\
W \\
\text { Ret } \\
\text { R } \\
\text { W }\end{array}$ & $\begin{array}{r}1592 \\
1956 \\
10000 \\
988 \\
1942 \\
10000 \\
652 \\
2582 \\
10000\end{array}$ \\
\hline $\begin{array}{c}\text { H. Y. } \\
25 \\
\text { years old } \\
\delta\end{array}$ & Typhoid & $\begin{array}{l}\text { Fever- } \\
\text { abating } \\
\text { Reconv. } \\
\text { Reconv. }\end{array}$ & 28 & $\begin{array}{r}37.4 \\
36.7 \\
36.3\end{array}$ & $\begin{array}{l}80 \\
86\end{array}$ & $\begin{array}{l}4.48 \\
4.42 \\
4.72\end{array}$ & $\begin{array}{l}6300 \\
5800 \\
6800 .\end{array}$ & $\begin{array}{l}87700 \\
78300 \\
94500\end{array}$ & $\begin{array}{c}\text { Ret } \\
\text { R } \\
\text { W } \\
\text { Ret } \\
\text { R } \\
W \\
\text { Ret } \\
\text { R } \\
W\end{array}$ & $\begin{array}{r}518 \\
1040 \\
10000 \\
820 \\
1406 \\
10000 \\
860 \\
1866 \\
10000\end{array}$ \\
\hline $\begin{array}{c}\text { H. K. } \\
33 \\
\text { years old } \\
\text { ? }\end{array}$ & Typhoid & $\begin{array}{l}\text { Acme } \\
\text { Fever- } \\
\text { abating } \\
\text { Reconv. }\end{array}$ & $\begin{array}{l}63 \\
83 \\
8\end{array}$ & $\begin{array}{r}39.1 \\
38.3 \\
36.6\end{array}$ & $\begin{array}{l}79 \\
77 \\
84\end{array}$ & $\begin{array}{l}4.15 \\
4.22 \\
4.40\end{array}$ & $\begin{array}{l}7000 \\
4800 \\
3300\end{array}$ & $\begin{array}{l}106400 \\
136500 \\
157500\end{array}$ & $\begin{array}{c}\text { Ret } \\
\text { R } \\
W \\
\text { Ret } \\
R \\
\text { W } \\
\text { Ret } \\
\text { R } \\
\text { W }\end{array}$ & $\begin{array}{r}402 \\
982 \\
10000 \\
1396 \\
2938 \\
10000 \\
662 \\
1788 \\
10000\end{array}$ \\
\hline $\begin{array}{c}\text { S. T. } \\
22 \\
\text { years old } \\
?\end{array}$ & Typhoid & $\begin{array}{l}\text { Acme } \\
\text { Fever- } \\
\text { abating } \\
\text { Acme }\end{array}$ & 52 & \begin{tabular}{r|}
39.1 \\
36.3 \\
39.4
\end{tabular} & 61 & $\begin{array}{l}3.16 \\
2.98 \\
2.64\end{array}$ & $\begin{array}{l}2600 \\
2500 \\
3200\end{array}$ & $\begin{array}{l}78400 \\
69800 \\
87450\end{array}$ & $\begin{array}{c}\text { Ret } \\
\text { R } \\
W \\
\text { Ret } \\
R \\
W \\
\text { Ret } \\
\text { R } \\
\text { W }\end{array}$ & $\begin{array}{r}1080 \\
3020 \\
10000 \\
78 \\
3086 \\
10000 \\
210 \\
2390 \\
10000\end{array}$ \\
\hline
\end{tabular}


Hematopoietic Function of Bone Marrow (1)

of the Mitosis in Leucopenia

\begin{tabular}{|c|c|c|c|c|c|c|c|c|c|c|c|c|c|c|c|c|c|c|}
\hline \multirow[b]{3}{*}{ 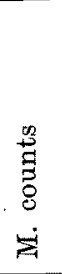 } & \multirow[b]{3}{*}{$\begin{array}{l}\dot{0} \\
\dot{-} \\
\dot{z}\end{array}$} & \multicolumn{17}{|c|}{ Appearance of mitosis } \\
\hline & & \multicolumn{7}{|c|}{ Erythropoiesis } & \multicolumn{10}{|c|}{ Leucopoiesis } \\
\hline & & 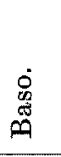 & $\begin{array}{l}\dot{3} \\
\frac{3}{0} \\
0\end{array}$ & $\dot{0}$ & 品 & 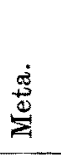 & $\stackrel{\Xi}{E}$ & $\frac{\dot{0}}{\tilde{E}}$ & $\dot{E}$ & غ & 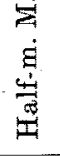 & $\begin{array}{l}\dot{\sum} \\
\dot{\Sigma} \\
\dot{\Sigma}\end{array}$ & $\begin{array}{l}\frac{3}{1} \\
\frac{8}{2} \\
\frac{0}{2}\end{array}$ & $\begin{array}{r}\dot{g} \\
\dot{8} \\
\dot{|r|}\end{array}$ & $\dot{B}$ & 这. & $\underset{\tilde{E}}{\dot{E}}$ & $\stackrel{\dot{0}}{\mathrm{E}}$ \\
\hline $\begin{array}{r}1 \\
26 \\
18 \\
0\end{array}$ & $\begin{array}{r}1.5 \\
48.5 \\
1.8 \\
0\end{array}$ & 4 & 8 & 14 & 16 & 4 & 2 & 4 & 0 & 2 & 8 & 8 & 0 & 0 & 4 & 8 & 4 & 2 \\
\hline $\begin{array}{l}38 \\
17\end{array}$ & $\begin{array}{r}35.5 \\
1.7\end{array}$ & 4 & 14 & 20 & 12 & 4 & 4 & 18 & 0 & 2 & 6 & 4 & 0 & 4 & 6 & 2 & 4 & 4 \\
\hline $\begin{array}{r}76 \\
23\end{array}$ & $\begin{array}{r}40.0 \\
2.3\end{array}$ & 16 & 32 & 24 & 32 & 16 & 8 & 20 & 0 & 4 & 10 & 8 & 0 & 0 & 14 & 6 & 2 & 0 \\
\hline $\begin{array}{r}3 \\
74 \\
20 \\
2\end{array}$ & $\begin{array}{r}1.9 \\
37.9 \\
20.0 \\
2.0\end{array}$ & 28 & 24 & 22 & 20 & 22 & 10 & 22 & 2 & 4 & 8 & 6 & 0 & 0 & 6 & 8 & 4 & 2 \\
\hline $\begin{array}{l}98 \\
38\end{array}$ & $\begin{array}{r}50.5 \\
3.8\end{array}$ & 30 & 48 & 20 & 58 & 16 & 6 & 18 & 4 & 4 & 14 & 16 & 0 & 0 & 14 & 16 & 4 & 4 \\
\hline $\begin{array}{r}0 \\
124 \\
21\end{array}$ & $\begin{array}{c}0 \\
45.4 \\
2.1\end{array}$ & 22 & 72 & 30 & 56 & 20 & 24 & 24 & 0 & 2 & 12 & 6 & 0 & 0 & 12 & 4 & 4 & 0 \\
\hline $\begin{array}{r}0 \\
40 \\
21 \\
2\end{array}$ & $\begin{array}{c}0 \\
38.5 \\
2.1 \\
2.4\end{array}$ & 10 & 14 & 16 & 22 & 14 & 0 & 4 & 0 & 4 & 8 & 8 & 0 & 0 & 8 & 6 & 2 & 4 \\
\hline $\begin{array}{l}66 \\
23\end{array}$ & $\begin{array}{r}46.9 \\
2.3\end{array}$ & 8 & 34 & 24 & 26 & 14 & 4 & 22 & 2 & 6 & 8 & 6 & 0 & 2 & 14 & 6 & 4 & 0 \\
\hline $\begin{array}{r}2 \\
72 \\
24\end{array}$ & $\begin{array}{r}2.3 \\
38.6 \\
2.4\end{array}$ & 20 & 28 & 24 & 38 & 16 & 8 & 10 & 0 & 9 & 10 & 6 & 0 & 0 & 18 & 4 & 0 & 2 \\
\hline $\begin{array}{r}0 \\
46 \\
24 \\
4\end{array}$ & $\begin{array}{r}0 \\
46.8 \\
2.4 \\
2.9\end{array}$ & 8 & 16 & 22 & 10 & 18 & 12 & 6 & 0 & 0 & 8 & 12 & 0 & 4 & 2 & 12 & 10 & 0 \\
\hline $\begin{array}{r}144 \\
28\end{array}$ & $\begin{array}{r}49.0 \\
2.8\end{array}$ & 34 & 56 & 54 & 52 & 50 & 24 & 18 & 2 & 8 & 10 & 8 & 0 & 0 & 4 & 16 & 8 & 0 \\
\hline $\begin{array}{r}104 \\
22\end{array}$ & $\begin{array}{r}1.5 \\
58.1 \\
2.2\end{array}$ & 26 & 48 & 30 & 44 & 28 & 20 & 12 & 0 & 6 & 4 & 10 & 0 & 2 & 8 & 6 & 6 & 2 \\
\hline $\begin{array}{r}2 \\
128 \\
20 \\
0\end{array}$ & $\begin{array}{c}2.0 \\
42.4 \\
2.0 \\
0\end{array}$ & 39 & 61 & 28 & 56 & 24 & 13 & 35 & 1 & 7 & 5 & 7 & 0 & 0 & 8 & 8 & 3 & 1 \\
\hline $\begin{array}{r}124 \\
22 \\
0\end{array}$ & $\begin{array}{c}40.2 \\
2.2 \\
0\end{array}$ & 30 & 44 & 34 & 52 & 28 & 22 & 20 & 0 & 2 & 12 & 8 & 0 & 0 & 16 & 2 & 2 & 2 \\
\hline $\begin{array}{l}86 \\
16\end{array}$ & $\begin{array}{r}35.9 \\
1.6\end{array}$ & 14 & 28 & 44 & 34 & 18 & 14 & 20 & 2 & 4 & 6 & 4 & 0 & 0 & 2 & 6 & 6 & 2 \\
\hline
\end{tabular}


as an expression of sufficiency and decrease as that of insufficiency of the bone marrow.

Fig. 2 shows the relation between the irritability of the bone marrow to stimulus of the pathogenetic microbes and the reaction of the bone marrow. The curve of irritability of the bone marrow runs parallel to the curve of fever with some lag, and the curve of mitosis is illustrated as a rising curve in the first phase and a lowering curve in the second phase, as shown in Fig. 2.
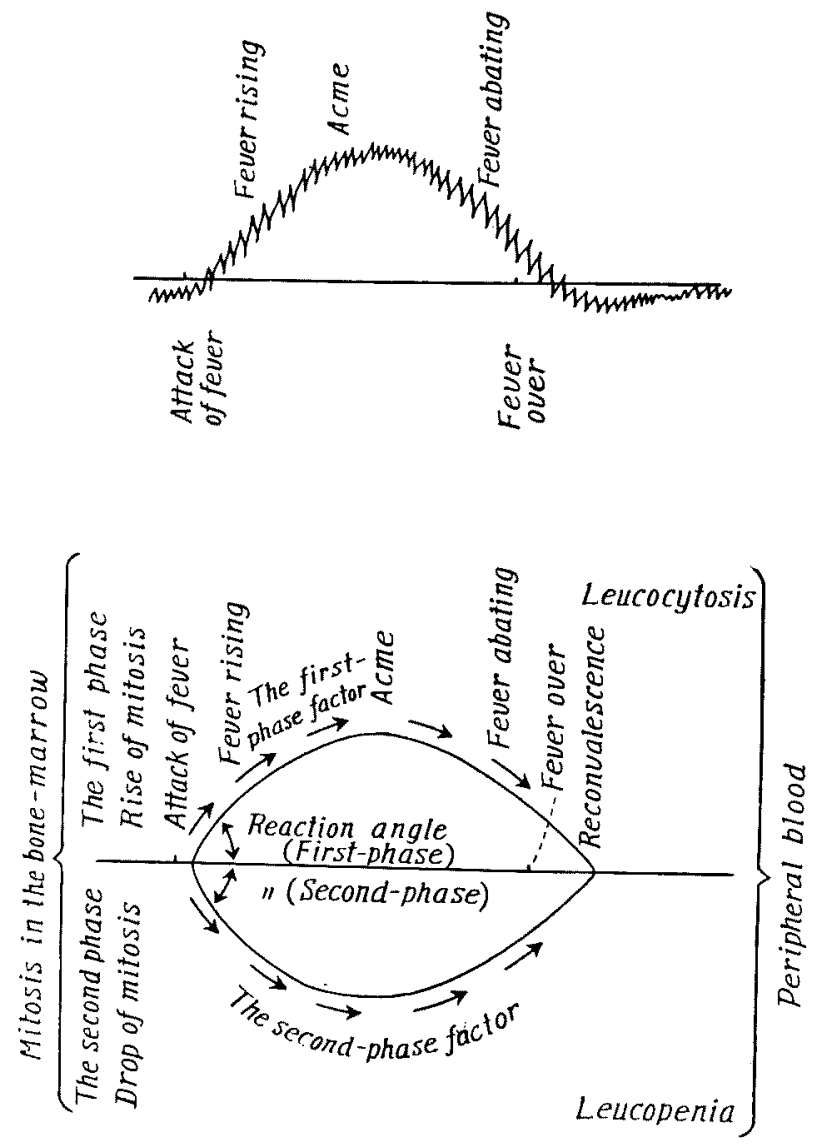

Fig. 2. Schemas of the irritability to stimulus and of the reaction mechanism of the leucopoietic system of the bone marrow.

If the angle that is made by a normal trend of mitosis and a trend toward increase or decrease of mitosis be called the reaction angle, the reaction angles in the first phase and the second phase are to be respectively called the first-phase reaction angle and the second-phase reaction angle; in the same way, a leucopoiesis in the first phase can be called a first-phase reaction and the one in the 
second phase a second-phase reaction.

The reaction angle is proportionate to the specificity, quality and quantity of the pathogenetic factors and the disposition of individuals. The pathogenetic microbes causing leucocytosis belong to the first-phase factors and those causing leucopenia to the second-phase factors.

In the cases more than two factors are added up, if these factors belong to the same phase, the curve of mitosis elevates or drops more strikingly according to the summation of factors in the same phase, while if thesef actors belong to the different phases, the curve of mitosis changes its trend upwards or downwards according to the differences of factors, as shown in Fig. 3. For instance, in a typhoid fever case complicated with pneumonia or intestinal perforation, if the first-phase factor is greater than the second-phase factor, the trend of mitosis changes from a lowering to a rising tendency and the curve of mitosis changes accordingly as shown in Figs. 3-1, showing an increase of leucocytes both in the bone marrow and peripheral blood according to the difference of the firstand second-phase factors. Figs. 3-2 show the opposite-tending curve in a scarlet

1)

The first phase
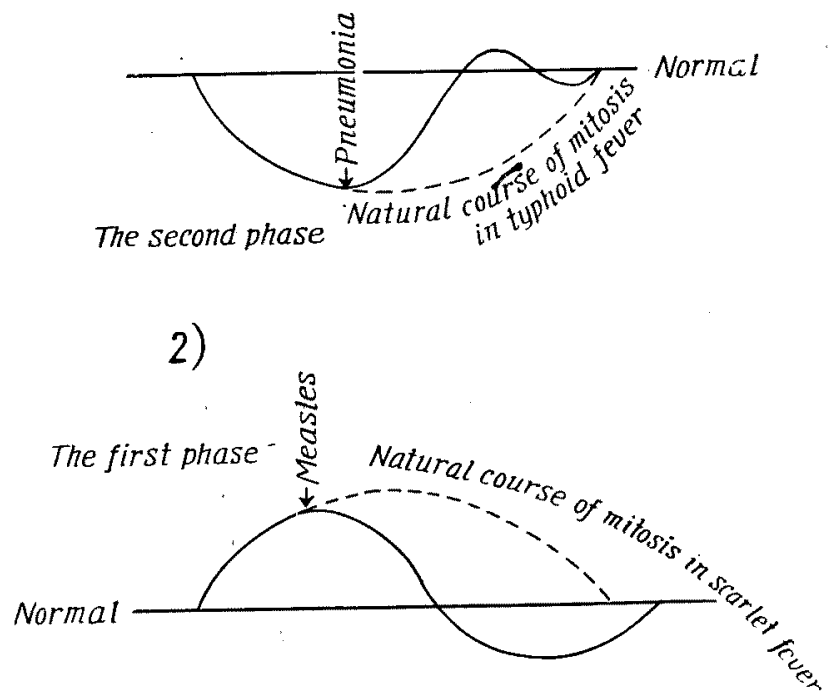

The second phase

Fig. 3. 1). Case in the second phase, in which in the course of the illness a second-phase factor is complicated with a first-phase factor (typhoid fever case complicated with pneumonia).

2). Case in the first phase, in which vice versa in the course of the illness a first-phase factor is complicated with a second-phase factor (scarlet fever case complicated with measles). 
fever complicated with measles.

C. Specificity of the two phase-factors

Here the specificity of stimulant factors is of great importance, and all stimulant factors of pathogenetic microbes and physico-chemical agents have their respective specificity not only biologically but also clinically. For example, the pathogenetic microbes of typhoid, paratyphoid A, paratyphoid K (salmonella Sendai) and paratyphoid B are called the germs of the typhoid group in our country and belong to the second-phase factors, but it can be found that even the factors belonging to the same phase factors they have all orderly and definitely the respective specificity, and that the reaction of the pathogenetic microbes against human body is the most active in typhoid bacilli, followed in descending order by paratyphoid $A, K$ and $B$ bacilli. The reaction angles of these secondphase factors are in the order of typhoid > paratyphoid $A>$ paratyphoid $K>$ paratyphoid B bacilli.

From these results it can be easily understood that in the peripheral blood leucopenia is the most striking in typhoid fever, moderate in paratyphoid $\mathrm{A}$ and $K$ and slight in paratyphoid $B$. Also similar differences can be observed in leucocytosis.

D. Relation between the Two Phase Factors and the Autonomic Nerve System

In my observations concerning the relation between the two phase factors and the autonomic nerve system, the first-phase factor causes sympathicotonia with a rise of mitosis and the second-phase factor vagotonia with a drop of mitosis.

\section{CONCLUSION}

The author has studied with the aid of Miyamoto's laborious work the causative mechanism of leucocytosis and leucopenia in various infectious diseases in order to seek the principle of hematopoiesis of the bone marrow.

These observations of hematopoiesis of the bone marrow in the courses of infectious diseases have gradually made the author think of an idea of "PHASES" of mitosis in the bone marrow. And the author has come to the conclusion regarding the principle of hematopoiesis in the bone marrow, that erythrocytes are formed monophasically in the erythropoietic system, while leucocytes diphasically in the leucopoietic system in the bone marrow.

\section{References}

1) Saito, A. \& Ono, T., Tohoku J. Exp. Med., 1958, 67, 253.

2) Saito, A. \& Shimoyama, K., ibid., 1958, 67, 265.

3) Saito, A. \& Miyamoto, T., ibid., 1958, 67, 341.

4) Saito, A., ibid., 1958, 68, 29.

5) Saito, A., ibid., 1958, 68, 151, 
6) Saito, A. \& Miyamoto, T., Tohoku Igaku Zassi (Jap.), 1954, 51, 97.

7) Miyamoto, T. \& Saito, A., Acta Haemat. Jap. (Jap.), 1955, 18, 246.

8) Miyamoto, T., ibid., 1955, 18, 647.

9) Saito, A., Ono, T., Shimoyama, K. \& Miyamoto, T., J.J.S.I.M. (Jap.), 1956, 45, 902.

10) Saito, A., Miyamoto, T., Shimoyama, K. \& Ono, T., Acta Haemat. Jap. (Jap.), 1957, 20, Suppl., 279.

11) Saito, A., Ono, T., Shimoyama, K. \& Miyamoto, T., J.J. Inf. D. (Jap.), 1957, 31, 175.

12) Saito, A., Igaku no Ayumi (Jap.), 1958, 26, 789.

13) Saito, A., J.J.S.I.M. (Jap.), 1958, 47, 1259.

14) Saito, A., ibid., 1958, 47, 1259.

15) Saito, A., Acta Haemat. Jap. (Jap.), 1958, 21, 111.

16) Naegeli, O., Blutkrankheiten u. Blutdiagnostik, 5 Aufl, 1931, 251.

17) Farady, M., Nippon Yakukyokuho Chukai (Jap.), 5 Ed. 1935, 265.

18) Rötgen, W. C., cited by Buckstein, The digestive tract in röntegenology, 2 Ed., Lippencott, Philadelphia, London, Montreal, 1953, 3.

19) Becquerel, A.H., eited by Nishikawa, Y., Naika Shinryo no Jissai (Jap.), 56 Ed., $1953,1813$.

20) Curie, P. \& M., ibid., 1813.

21) Rohr, K., Das Menschliche Knochenmark, Georg Thieme, Leipzig, 1940, 171. 